\title{
Model Berbasis Portofolio untuk Meningkatkan Partisipasi Belajar Siswa pada Pembelajaran PKN
}

\author{
Hasnawati \\ SDN 11 Batang Anai Kabupaten Padang Pariaman
}

\begin{abstract}
Abstrak
At SDN 11 Batang Anai, participation of $4^{\text {th }}$ grade students in civic learning was low, either in discussing, asking question, or taking conclusion. Teacher used to implement expository method in classroom. This study is a classroom action research that aimed to improve students' participation in learning civic subject by using model of portfolio-based. In cycle I, percentage of students' participation for discussing is $58.92 \%, 49.80 \%$ for asking question, and $33.92 \%$ for taking conclusion. In cycle II, percentage of students' participation for discussing is $84.45 \%, 72.73 \%$ for asking question, and $70.95 \%$ for taking conclusion. Hence, civics learning that implement model of portfolio-based can improve students' participation in learning.
\end{abstract}

Kata Kunci: learning participation, model of portfolio-based, civics subject

\section{PENDAHULUAN}

Pendidikan Kewarganegaraan (PKn) merupakan salah satu mata pelajaran wajib yang ada dalam kurikulum pendidikan, baik di tingkat pendidikan dasar, pendidikan menengah maupun perguruan tinggi. PKn memiliki tujuan utama yaitu membentuk warga negara yang baik dan berkarakter sesuai dengan Pancasila dan UUD 1945. PKn merupakan subjek pembelajaran yang mengemban misi untuk membentuk kepribadian bangsa, yang mempunyai karakter. Pendidikan Kewarganegaraan merupakan mata pelajaran yang secara umum bertujuan untuk mengembangkan potensi individu warga negara indonesia, sehingga memiliki wawasan sikap, dan keterampilan kewarganegaraan yang memadai dan memungkinkan untuk berpartisipasi secara cerdas dan bertanggung jawab dalam berbagai kehidupan bermasyarakat, berbangsa dan bernegara (Depdiknas, 2006).

Tujuan pembelajaran PKn adalah untuk membekali peserta didik dengan pengetahuan dan kemampuan dasar yang berkenaan dengan hubungan antara warga negara dan untuk mengembangkan nilai-nilai luhur dan dapat diwujudkan dalam kehidupan sehari-hari. Sebaiknya, dengan pembelajaran PKn diharapkan mata pelajaran PKn dapat dilaksanakan dengan baik dan mampu menyiapkan warga negara yang baik. Tidak dapat dipungkiri bahwa sampai saat ini, keadaan pembelajaran Pendidikan Kewarganegaraan (PKn) di Sekolah Dasar (SD) masih kurang menggembirakan. Berdasarkan pra penelitian di kelas IV SDN 11 Batang Anai memberikan gambaran fakta bahwa pembelajaran PKn masih menemui banyak kelemahan dan kendala yang dihadapi. Ternyata mata pelajaran PKn sampai saat ini masih dianggap sebagai mata pelajaran yang tidak disukai dan membosankan oleh sebagian siswa. 
Pada proses pembelajaran PKn, guru cenderung menggunakan metode ceramah dan tanya jawab. Seperti yang diketahui, metode ceramah adalah metode yang berpusat pada guru. Pada waktu guru menyuruh siswa berdiskusi, siswa seolah-olah bekerja semuanya. Akan tetapi ketika diminta guru untuk menyampaikan hasil diskusinya ke depan kelas, tidak satu orang pun yang berani, dan apabila sudah dipaksa, baru siswa maju ke depan. Ketika siswa diminta guru untuk bertanya jika ada yang belum mengerti, maka tidak ada seorang pun siswa yang tampak mengacungkan tangan. Ketika guru memberikan tugas di akhir pembelajaran maka banyak dari siswa kelas IV tersebut yang tidak menyelesaikan tugas tersebut dan banyak ditemukan jawaban yang tidak benar. Ketika diminta guru untuk menyimpulkan pelajaran, tidak ada satu pun yang berani.

Hasil wawancara peneliti dengan guru kelas IV, bahwa proses pembelajaran PKn, memang terlihat siswa pasif dan kurang berpartisipasi. Ini disebabkan metode yang dipakai guru adalah ceramah dan tanya jawab. Sedangkan metode yang lainnya jarang digunakan seperti diskusi. Walaupun metode diskusi ada digunakan oleh guru tersebut, tetapi dalam pelaksanaannya banyak siswa yang tidak bekerja dan hanya mengandalkan teman yang pintar. Rendahnya partisipasi siswa dalam pembelajaran tidak dapat dibiarkan, dan karena itu diperlukan suatu upaya untuk menimbulkan partisipasi belajar siswa. Di sini, peneliti memberikan solusi terhadap masalah tersebut, yaitu menerapkan pembelajaran dengan model pembelajaran berbasis portofolio.

Menurut Budimansyah (dalam Inayah, 2010), portofolio diartikan sebagai kumpulan pekerjaan peserta didik dengan maksud tertentu dan terpadu yang diseleksi menurut panduan-panduan yang ditentukan. Portofolio biasanya merupakan karya terpilih dari seorang siswa. Tetapi dapat juga berupa karya terpilih dari satu kelas secara keseluruhan yang bekerja secara kooperatif membuat kebijakan untuk memecahkan masalah. Sedangkan portofolio sebagai model pembelajaran adalah suatu kumpulan pekerjaan peserta didik dengan maksud tertentu dan terpadu yang diseleksi menurut panduan-panduan yang ditentukan. Panduan-panduan ini beragam tergantung pada mata pelajaran dan tujuan penilaian portofolio itu sendiri. Portofolio biasanya merupakan karya terpilih dari seorang siswa, tetapi dapat juga berupa karya terpilih dari suatu kelas secara keseluruhan yang bekerja secara kooperatif membuat kebijakan untuk mengatasi masalah. Menurut Fajar (2004), portofolio sebagai model pembelajaran terbagi dalam dua bagian, yakni portofolio tanyangan dan portofolio dokumentasi. Dalam model pembelajaran ini, siswa dituntut untuk berpikir cerdas, kreatif, parisipatif, prospektif dan bertanggung jawab yang tentu saja akan berpengaruh pada tingkat partisipasi belajarnya.

\section{METODE}

Jenis penelitian yang digunakan peneliti adalah Penelitian Tindakan Kelas (PTK). PTK adalah penelitian yang dilakukan oleh guru di dalam kelasnya sendiri melalui refleksi diri dengan tujuan untuk memperbaiki kinerjanya sebagai seorang guru sehingga hasil belajar siswa meningkat. PTK ini dilakukan secara kolaborasi oleh peneliti bersama guru kelas IV di SDN 11 Batang Anai. Selain melakukan tindakan dalam proses pembelajaran, peneliti juga dibantu guru dalam merefleksikan kegiatan pembelajaran yang telah berlangsung yang bertujuan untuk memperbaiki atau meningkatkan kualitas proses pembelajaran di kelas. Arikunto, dkk. (2006) memandang, "PTK sebagai bentuk penelitian yang bertujuan untuk meningkatkan partisipasi belajar siswa, sehingga penelitian harus menyangkut upaya guru dalam bentuk proses pembelajaran". PTK, selain bertujuan untuk meningkatkan partisipasi belajar, juga untuk meningkatkan kinerja guru dalam proses pembelajaran. Dengan kata lain, PTK bukan hanya bertujuan untuk mengungkapkan penyebab dari berbagai permasalahan yang dihadapi, tetapi yang lebih penting adalah memberikan pemecahan berupa tindakan untuk mengatasi masalah.

Subjek penelitian adalah siswa kelas IV SDNegeri 11 Batang Anai yang berjumlah 36 orang. Indikator keberhasilan dalam proses pembelajaran diukur dengan menggunakan Kriteria Ketuntasan Minimal (KKM) dan indikator partisipasi siswa. KKM pada mata pelajaran PKn adalah 70. Indikator pada partisipasi siswa meningkat apabila (1) partisipasi siswa saat berdiskusi terhadap materi meningkat pada kriteria baik atau minimal sampai 70\%; (2) partisipasi siswa dalam bertanya terhadap materi meningkat pada kriteria baik atau minimal sampai 65\%; (3) partisipasi siswa dalam 
menyimpulkan pelajaran terhadap materi meningkat pada kriteria baik atau minimal sampai $60 \%$. Dalam penelitian ini, peneliti menggunakan instrumen lembar observasi partisipasi siswa, lembar observasi kegiatan pengajaran, dan lembar soal tes.

\section{HASIL}

\section{Deskripsi Siklus I}

Siklus I dilaksanakan dalam dua kali pertemuan. Selama pembelajaran berlangsung, peneliti dibantu oleh observer untuk melakukan pengamatan dengan menggunakan lembar pengamatan yang telah disiapkan.

\section{Perencanaan}

Pada tahap ini peneliti membuat persiapan untuk melaksanakan tindakan pada siklus I. Persiapan tersebut disusun dan diwujudkan dalam bentuk rencana pelaksanaan pembelajaran (RPP), pembuatan RPP ini disusun secara kolaboratif antara peneliti dengan guru kelas IV berdasarkan program semester II sesuai dengan waktu penelitian berlangsung. Perencanaan pada siklus I ini disusun untuk 2 kali pertemuan ( 4 x 35 menit) dengan alokasi waktu 1 kali pertemuan 2 x 35 menit.

\section{Pelaksanaan}

Dalam pelaksanaan tindakan, peneliti bertindak sebagai guru, kepala sekolah sebagai observer melakukan pengamatan terhadap tindakan yang dilakukan guru dan siswa selama pembelajaran berlangsung. Tahap-tahap kegiatan pembelajaran pada setiap pertemuan yaitu: (1) kegiatan awal, (2) kegiatan inti, (3) kegiatan akhir. Ketiga tahap ini tidak berdiri sendiri, melainkan terkait dengan kegiatan satu dengan kegiatan yang lainnya.

\section{Pengamatan}

Hasil analisis observer terhadap pelaksanaan pembelajaran menunjukkan bahwa pembelajaran yang peneliti laksanakan berlangsung kurang baik. Begitu juga halnya dengan pengamatan dengan pengamatan terhadap partisipasi siswa dalam pembelajaran yang belum optimal.

Tabel 1. Observasi Aktivitas Guru pada Siklus I

\begin{tabular}{cccc}
\hline \multicolumn{2}{c}{ Pertemuan } & Jumlah skor & Persentase \\
\hline I & & 9 & $60 \%$ \\
II & Rata-rata & 10 & $66,66 \%$ \\
& & & $63,33 \%$ \\
\hline
\end{tabular}

Persentase aktivitas guru dalam mengelola pembelajaran memiliki rata-rata persentase $63,33 \%$, sehingga sudah dapat dikatakan cukup tetapi belum mencapai indikator keberhasilan $70 \%$.

Tabel 2. Hasil Observasi Partispasi Siswa pada Siklus I

\begin{tabular}{|c|c|c|c|c|c|}
\hline \multirow[t]{3}{*}{ Indikator } & \multicolumn{4}{|c|}{ Pertemuan } & \multirow{3}{*}{$\begin{array}{c}\text { Rata-Rata \% } \\
\text { Indikator }\end{array}$} \\
\hline & \multicolumn{2}{|l|}{$\mathbf{I}$} & \multicolumn{2}{|l|}{ II } & \\
\hline & Jumlah Skor & $\%$ & Jumlah Skor & $\%$ & \\
\hline Melaksanakan diskusi & 19 & 52,77 & 23 & 63,88 & 58,32 \\
\hline Bertanya & 15 & 41,66 & 19 & 52,77 & 47,21 \\
\hline Menyimpulkan pelajaran & 9 & 25 & 15 & 41,66 & 33,33 \\
\hline Jumlah siswa & \multicolumn{2}{|l|}{36} & \multicolumn{2}{|l|}{36} & \\
\hline
\end{tabular}


Masih banyak siswa yang belum berpartisipasi dalam proses pembelajaran khususnya pada indikator 2 dan 3. Hal ini disebabkan model yang digunakan peneliti sangatlah berbeda dengan yang sebelumnya. Siswa masih menganggap model yang digunakan oleh peneliti dalam proses pembelajaran masih baru, sehingga siswa belum terbiasa dan terpartisipasi dalam proses pembelajaran dengan baik di dalam kelas sewaktu dengan model ini.

Tabel 3 . Hasil Belajar Siswa pada Siklus I

\begin{tabular}{clc}
\hline No & \multicolumn{1}{c}{ Uraian } & Jumlah \\
\hline $\mathbf{1}$ & Jumlah siswa yang mengikuti tes & 32 \\
$\mathbf{2}$ & Jumlah siswa yang tuntas & 12 \\
$\mathbf{3}$ & Jumlah siswa yang belum tuntas & 20 \\
& Presentase ketuntasan & $37,50 \%$ \\
& Rata- rata nilai tes & 51,87 \\
\hline
\end{tabular}

Persentase ketuntasan hasil belajar siswa pada tes akhir siklus secara keseluruhan masih tergolong rendah dan rata-rata nilai tes secara keseluruhan belum mencapai KKM yang ditetapkan. Dapat dijelaskan pada masing-masing data hasil belajar siswa yaitu: Nilai tes siswa yang terendah adalah 30 dan nilai tes siswa yang tertinggi adalah 80. Nilai siswa yang memperoleh nilai di atas KKM ada sebanyak 12 orang, sedangkan siswa yang memperoleh nilai di bawah KKM ada sebanyak 20 orang, dan siswa yang tidak hadir dalam mengikuti ulangan harian I ada 3 orang siswa. Dalam target ketuntasan belajar yang ditetapkan oleh peneliti pada indikator keberhasilan ketuntasan belajar secara klasikal yaitu 70 dari jumlah siswa, sedangkan ketercapaian ketuntasan belajar pada siklus I ini belum mencapai target ketuntasan belajar, dan peneliti ingin meningkatkannya pada siklus II untuk mencapai target ketuntasan belajar secara klasikal.

\section{Refleksi}

Kegiatan refleksi dilakukan secara kolaboratif antara peneliti dan observer yang dilakukan pada setiap siklus berakhir. Siklus I ini mencakup refleksi terhadap perencanaan, pelaksanaan tindakan, observasi, evaluasi dan hasil yang diperoleh oleh siswa. Dari pelaksanaan tindakan dan observasi pada siklus I, tingkat partisipasi siswa pada indikator partisipasi yang dilakukan oleh siswa masih sangat sedikit, ini terlihat pada indikator 2 dan 3. Peneliti bersama observer menyimpulkan masalah yang dihadapi peneliti dalam mengelola pembelajaran adalah peneliti masih terfokus pada kegiatan diskusi dan kurang maksimalnya peneliti dalam melakukan model Pembelajaran Berbasis Portofolio dalam pembelajaran PKn.

Melihat analisis tes hasil belajar siswa pada siklus I, dapat disimpulkan bahwa hasil belajar siswa belum tercapai target yang diinginkan. Persentase tersebut dapat dilihat dari siswa yang tuntas belajar masih di bawah $70 \%$ yaitu hanya 12 orang siswa. Untuk mengatasi hal ini, yang perlu ditingkatkan adalah peneliti memberikan motivasi kepada siswa untuk lebih giat lagi dalam belajar sehingga partisipasi siswa untuk belajar melakukan diskusi secara kelompok, bertanya, dan menyimpulkan pelajaran. Ketika diskusi kelompok akan meningkat pada pembelajaran selanjutnya. Selain itu peneliti akan meningkatkan kemampuan siswa dalam bertanya di saat persentase kelompok di depan kelas. sehingga partisipasi bertanya siswa ketika diskusi dan persentase dapat dituangkan di depan kelas. Selain itu peneliti akan memaksimalkan waktu dalam proses pelaksanaan pembelajaran sesuai dengan RPP.

\section{Deskripsi Siklus II}

\section{Perencanaan}

Hasil analisis pada siklus I menunjukkan subjek penelitian belum mencapai tujuan pembelajaran yang diharapkan. Karena itu pembelajaran dilanjutkan dengan siklus II. Pembelajaran pada siklus II dilakukan agar siswa lebih terbiasa dengan strategi pembelajaran yang dilakukan yaitu pembelajaran PKn dengan menggunakan model Pembelajaran Berbasis Portofolio dalam meningkatkan partisipasi belajar siswa melalui kegiatan aktif dalam pembelajaran sehingga pembelajaran yang diberikan menjadi lebih bermakna. Pembelajaran pada siklus ini juga dilakukan 2 kali pertemuan dengan alokasi waktu 2x35 menit. 


\section{Pelaksanaan}

Siklus II dilaksanakan 2 kali pertemuan. Adapun pelaksanaan pembelajaran pada siklus II ini terdiri dari kegiatan awal, inti, dan akhir. Selanjutnya di akhir tindakan, guru memberikan latihan kepada siswa untuk mereka kerjakan. Dalam mengerjakan latihan, guru mengawasi dan membimbing siswa agar latihan tersebut dapat dikerjakan dengan baik. Setelah latihan selesai dikerjakan, siswa diminta untuk mengumpulkannya kedepan kelas dengan tertib.

\section{Pengamatan}

Pengamatan (observasi) dilakukan untuk setiap kali pertemuan, yaitu mengisi lembar observasi partisipasi siswa dalam pembelajaran PKn dengan model Pembelajaran Berbasis Portofolio di kelas IV . Pada akhir siklus diberikan tes hasil belajar berupa ulangan harian. Hasil analisis observer terhadap pelaksanaan pembelajaran menunjukkan bahwa pembelajaran yang peneliti laksanakan berlangsung baik. Begitu juga halnya dengan pengamatan terhadap partisipasi siswa dalam pembelajaran.

Tabel 4. Observasi Aktivitas Guru pada Siklus II

\begin{tabular}{|c|c|c|}
\hline Pertemuan & Jumlah Skor & Persentase (\%) \\
\hline I & 11 & 73,33 \\
\hline II & 13 & 86,66 \\
\hline \multicolumn{2}{|c|}{ Rata-rata } & 79,99 \\
\hline
\end{tabular}

Persentase kegiatan guru dalam mengelola pembelajaran memiliki rata-rata persentase $79,99 \%$ sehingga sudah dapat dikatakan baik dan telah mencapai indikator keberhasilan yang ditetapkan oleh peneliti.

Tabel 5. Observasi Partisipasi pada Siklus II

\begin{tabular}{|c|c|c|c|c|c|}
\hline \multirow[t]{3}{*}{ Indikator } & \multicolumn{4}{|c|}{ Pertemuan } & \multirow{3}{*}{$\begin{array}{l}\text { Rata-rata } \\
\text { Presentase }\end{array}$} \\
\hline & \multicolumn{2}{|c|}{$\mathbf{I}$} & \multicolumn{2}{|c|}{ II } & \\
\hline & $\begin{array}{l}\text { Jumlah } \\
\text { Skor }\end{array}$ & $\%$ & $\begin{array}{l}\text { Jumlah } \\
\text { Skor }\end{array}$ & $\%$ & \\
\hline Melaksanakan diskusi & 25 & 69,44 & 27 & 75 & 72,22 \\
\hline Bertanya & 23 & 63,88 & 25 & 69,44 & 66,66 \\
\hline $\begin{array}{l}\text { Menyimpulkan } \\
\text { pelajaran }\end{array}$ & 19 & 52,77 & 23 & 63,88 & 58,32 \\
\hline Jumlah siswa & & & & & - \\
\hline
\end{tabular}

Pada siklus II ini terlihat hampir semua siswa berpartisipasi dalam model pembelajaran berbasis portofolio hal ini disebabkan siswa sudah mulai bisa melakukan setiap indikator yang ditetapkan oleh peneliti.

Tabel 6. Hasil Belajar Siswa pada Siklus II

\begin{tabular}{ccc}
\hline No & Uraian & Jumlah \\
\hline $\mathbf{1}$ & Jumlah siswa yang mengikuti tes & 30 \\
$\mathbf{2}$ & Jumlah siswa yang tuntas & 23 \\
$\mathbf{3}$ & Jumlah siswa yang belum tuntas & 7 \\
& Presentase ketuntasan & $\mathbf{7 6 , 6 6 \%}$ \\
& Rata- rata nilai tes & $\mathbf{7 0 , 8 3}$ \\
\hline
\end{tabular}

Ketuntasan hasil belajar siswa pada tes secara keseluruhan sudah tergolong tinggi dan ratarata nilai tes secara keseluruhan telah mencapai KKM yang ditetapkan. Dapat dijelaskan pada masing-masing data hasil belajar siswa yaitu: nilai tes yang terendah 45 dan nilai tes yang 
tertinggi 85 pada siklus II. Siswa yang memperoleh nilai di atas KKM ada sebanyak 23 orang, sedangkan siswa yang memperoleh nilai di bawah KKM ada sebanyak 7 orang dan siswa yang tidak hadir dalam mengikuti tes akhir siklus II ada 6 orang siswa.

Dalam target persentase ketuntasan belajar yang ditetapkan oleh peneliti pada indikator keberhasilan yang telah ditetapkan yaitu $70 \%$ dari jumlah siswa, sedangkan ketercapaian ketuntasan belajar pada siklus II ini sudah mencapai indikator keberhasilan yang telah ditetapkan, bahkan melebihi yaitu 76,66\% dari jumlah siswa yang mengikuti ulangan harian. Sedangkan rata-rata hasil belajar yang di dapat pada siklus II sudah mencapai indikator keberhasilan yang telah ditetapkan yaitu $\geq 70$.

\section{Refleksi}

Hasil observasi didiskusikan dengan observer, tujuannya untuk mendapatkan gambaran tentang pelaksanaan tindakan pada siklus II. Berdasarkan gambaran yang diperoleh bahwa partisipasi belajar siswa pada indikator I, II, dan III mengalami peningkatan. Gambaran yang diperoleh dari kegiatan guru dalam proses pelaksanaan pembelajaran sudah sangat baik dari sebelumnya. Melihat analisis tes hasil belajar siswa pada siklus II, dapat disimpulkan bahwa hasil tes akhir siklus sudah tercapai target hasil belajar yang diinginkan, baik presentase ketuntasan belajar maupun rata-rata skor tes. Persentase tersebut dapat dilihat dari jumlah siswa yang telah tuntas belajar, yaitu di atas $70 \%$, dan rata-rata sudah di atas Kriteria Ketuntasan Minimal (KKM) yaitu 70.

\section{PEMBAHASAN}

Penelitian tindakan kelas ini terdiri dari dua siklus yang setiap siklusnya terdiri dari dua kali pertemuan dan 1 kali tes hasil belajar pada akhir siklus. Pelaksanaan pembelajaran yang dilaksanakan dengan model Pembelajaran Berbasis Portofolio. Penelitian ini menggunakan instrumen penelitian berupa lembar lembar observasi aktivitas guru, observasi partisipasi siswa, dan tes hasil belajar siswa berupa tes pada setiap akhir siklus. Pembelajaran dengan model Pembelajaran Berbasis Portofolio membuat siswa semangat dalam belajar kelompok. Dengan model Pembelajaran Berbasis Portofolio akan membuat siswa berani dan bisa mengemukakan pendapatnya serta menyimpulkan pembelajaran.

Tabel 7. Observasi Aktivitas Guru pada Siklus I dan Siklus II

\begin{tabular}{cc}
\hline Siklus & Persentase (\%) \\
\hline I & 63,33 \\
II & 79,99 \\
Rata-rata & 71,66 \\
\hline
\end{tabular}

Pelaksanaan pembelajaran PKn dengan model pembelajaran berbasis portofolio dapat meningkat aktivitas guru dalam proses pelaksanaan pembelajaran. Hal ini terlihat adanya peningkatan persentase aktivitas guru dalam proses pelaksanaan pembelajaran pada siklus I ke siklus II mengalami peningkatan dari $63,33 \%$ ke 79,99\%. Peningkatan aktivitas guru dalam proses pelaksanaan pembelajaran diebabkan peneliti sudah bisa melaksanakan pembelajaran PKn dengan model pembelajaran berbasis portofolio.

Persentase rata-rata partisipasi siswa pada umumnya mengalami peningkatan. Pembelajaran dengan model pembelajaran berbasis portofolio dapat meningkatkan partisipasi belajar siswa ke arah yang lebih baik. 
Tabel 8. Observasi Partisipasi Siswa pada Siklus I dan Siklus II

\begin{tabular}{lcc}
\hline \multicolumn{1}{c}{ Indikator Partisipasi Siswa } & \multicolumn{2}{c}{ Rata-rata persentase (\%) } \\
\cline { 2 - 3 } Siswa dalam melaksanakan diskusi & Siklus I & Siklus II \\
Siswa dalam bertanya & 58,32 & 72,22 \\
Siswa dalam menyimpulkan pembelajaran & 47,21 & 66,66 \\
& 33,33 & 58,32 \\
\hline
\end{tabular}

Pembelajaran PKn dengan model Pembelajaran Berbasis Portofolio yang dilaksanakan dapat meningkatkan partisipasi siswa dalam proses pelaksanaan pembelajaran. Hal ini terlihat adanya peningkatan rata-rata persentase untuk masing-masing indikator partisipasi siswa dari siklus I ke siklus II yaitu: indikator siswa dalam melaksanakan diskusi mengalami peningkatan dari 58,32\% ke $72,22 \%$, indikator siswa berani dalam bertanya mengalami peningkatan dari $47,21 \%$ ke $66,66 \%$, untuk indikator siswa dalam menyimpulkan pelajaran mengalami peningkatan dari 33,33\% ke $58,32 \%$. Peningkatan partisipasi belajar siswa pada pembelajaran PKn dengan menggunakan model Pembelajaran Berbasis Portofolio ini, membuat siswa akan lebih semangat belajar diskusi secara kelompok. Peneliti dalam proses pelaksanaan pembelajaran sudah baik dalam melaksanakan keterampilan dalam berdiskusi sekaligus memberikan arahan kepada siswa untuk dapat bertanya dan menyimpulkan pelajaran. Data mengenai hasil belajar siswa diperoleh melalui tes hasil belajar di akhir siklus.

Tabel 9. Hasil Belajar Siswa pada Siklus I dan Siklus II

\begin{tabular}{lcc}
\hline \multicolumn{1}{c}{ Siklus } & $\begin{array}{c}\text { Persentase Siswa yang Telah } \\
\text { Mencapai Nilai 70 }\end{array}$ & $\begin{array}{c}\text { Persentase Siswa yang Belum } \\
\text { Mencapai Nilai 70 }\end{array}$ \\
\hline Siklus I & $37,50 \%$ & $62,50 \%$ \\
Siklus II & $76,66 \%$ & $23,33 \%$ \\
\hline
\end{tabular}

Hasil belajar siswa dalam 2 siklus, terlihat bahwa pada siklus I, siswa yang tuntas belajar $37,50 \%$ dan yang belum tuntas belajar $62,50 \%$, dengan nilai rata-rata secara klasikal 51,86 . Sedangkan pada siklus II, siswa yang tuntas belajar $76,66 \%$ dan yang belum tuntas belajar hanya $23,33 \%$, dengan nilai rata-rata secara klasikal 73,45. Dengan demikian dapat disimpulkan bahwa persentase ketuntasan belajar siswa dari siklus I ke siklus II mengalami peningkatan dan sudah mencapai standar nilai KKM serta indikator keberhasilan secara klasikal yang terlihat pada tabel di atas. Berdasarkan hasil analisis data di atas, dapat disimpulkan bahwa pembelajaran dengan model Pembelajaran Berbasis Portofolio dapat meningkatkan partisipasi dan hasil belajar PKn siswa karena peneliti memberikan suatu strategi dalam pembelajaran yang sangat menarik partisipasi belajar siswa, dalam partisipasi ini siswa dibuat dalam kelompok dan dari kelompok tersebut siswa belajar bersama-sama dengan teman-temannya, dari cara belajar siswa yang bersemangat akhirnya dapat meningkatkan hasil belajar PKn siswa kelas IV SD Negeri 11 Batang Anai.

\section{KESIMPULAN}

Peningkatan partisipasi siswa kelas IV SD Negeri 11 Batang Anai pada pembelajaran PKn dengan model pembelajaran berbasis portofolio pada siklus I, indikator siswa dalam melaksanakan diskusi 58,32\% dan meningkat pada siklus II menjadi 72,22\%. Peningkatan partisipasi belajar siswa kelas IV SD Negeri 11 Batang Anai pada pembelajaran PKn dengan model pembelajaran berbasis portofolio, pada siklus I indikator partisipasi siswa dalam bertanya adalah 47,21\% dan meningkat pada siklus II menjadi 66,66\%. Peningkatan partisipasi belajar siswa kelas IV SD Negeri 11 Batang Anai pada pembelajaran PKn dengan model pembelajaran berbasis portofolio, pada siklus I indikator partisipasi siswa dalam menyimpulkan pelajaran adalah 33,33\% dan meningkat pada siklus II menjadi 58,32\%. Dengan demikian, maka dapat disimpulkan bahwa penerapan pembelajaran PKn berbasis portofolio dapat meningkatkan partisipasi belajar siswa. 


\section{SARAN}

Bagi guru yang melaksanakan pembelajaran dengan model pembelajaran berbasis portofolio dapat dijadikan salah satu strategi alternatif dalam pelaksaanaan pembelajaran PKn. Guru sebaiknya membiasakan siswa untuk belajar secara diskusi agar siswa bisa mengeluarkan pendapatnya dan menyimpulkan pelajaran. Bagi siswa, agar bisa membiasakan diri untuk dapat belajar secara diskusi, sehingga pemahaman siswa terhadap pembelajaran dapat meningkat.

\section{DAFTAR RUJUKAN}

Arikunto, Suharsimi, dkk. (2006). Penelitian Tindakan Kelas. Jakarta: Bumi Aksara.

Depdiknas. (2006). Kurikulum Tingkat Satuan Pendidikan Jenjang Pendidikan Dasar. Jakarta: Depdiknas.

Fajar, Arnie. (2004). Portofolio dalam Pembelajaran IPS. Bandung: Remaja Rosdakarya.

Inayah, Khoirotul. (2010). "Penerapan Model Pembelajaran Berbasis Portofolio Untuk Meningkatkan Motivasi Belajar Sosiologi Kelas X-A di MAN Malang I”. Skripsi Program Studi Pendidikan Ekonomi Jurusan Pendidikan IPS. Malang: Fakutas Tarbiyah Universitas Islam Negeri Maulana Malik Ibrahim.

Mulyasa, E. (2006). Kurikulum yang Disempurnakan: Pengembangan Standar Kompetensi dan Kompetensi Dasar. Bandung: Remaja Rosda Karya.

Pebriyenni. (2007). Pembelajaran Ilmu Pengetahuan Sosial Kelas Awal. Padang: FKIP Universitas Bung Hatta.

Ruminiati. (2007). Pengembangan Pendidikan Kewarganegaraan SD. Jakarta: Dirjen Dikti Depdiknas.

Yusrizal. (2010). Bahan Ajar Pembelajaran PKn SD Kelas Tinggi. Padang: Jurusan PGSD FKIP Universitas Bung Hatta. 